TEKNIK, 40 (3), 2019, 195-202

\title{
Rancang Bangun Sistem Informasi Monitoring Menggunakan Metode Agile dengan Dynamic System Development Model Guna Mendukung Gender Mainstreaming Strategy (Studi Kasus: Politeknik Caltex Riau)
}

\author{
Syevira Salsabila, Anggy Trisnadoli ${ }^{*}$ Istianah Muslim \\ Jurusan Teknologi Informasi, Politeknik Caltex Riau, \\ Jl. Umbansari (Patin) No. 1 Rumbai Pekanbaru, Riau, Indonesia 28265
}

\begin{abstract}
Abstrak
Gender merupakan isu yang harus diperhatikan oleh setiap institusi pendidikan. Kesenjangan gender dalam berbagai masalah terkait pengelolaan institusi akan menimbulkan dampak terhadap ketidakadilan gender. Solusi dari permasalahan tersebut adalah adanya dokumen Rencana Strategi Pengarusutamaan Gender (Renstra PUG) pada setiap institusi pendidikan. Penelitian ini bertujuan untuk membangun sebuah Sistem Informasi Monitoring menggunakan metode Agile dengan model Dynamic System Development Model (DSDM) guna Mendukung Gender Mainstreaming Strategy. Studi kasus pada Politeknik Caltex Riau. Sistem informasi yang dibangun mampu menampilkan informasi yang update dan akurat. Ini mendukung pimpinan institusi dalam pengambilan keputusan dan penentuan kebijakan terhadap gender. Hasil penelitian telah diuji secara fungsional dan divalidasi oleh expert.
\end{abstract}

Kata kunci: kesetaraan gender; gender mainstreaming strategy; agile; DSDM; renstra PUG

\begin{abstract}
[Title: Design of Monitoring Information System Using Agile Method with Dynamic System Development Model to Support Gender Mainstreaming Strategy (Case Study: Politeknik Caltex Riau)] Gender is an issue that must be considered by every educational institution. Gender disparities in various issues related to institutional management will have an impact on gender inequality. The solution to this problem is the existence of a Gender Mainstreaming Strategy Plan (Renstra PUG) document in each educational institution. This study aims to build a Monitoring Information System using the Agile method with a Dynamic System Development Model (DSDM) to Support Gender Mainstreaming Strategy. Case study at the Politeknik Caltex Riau. The information system built is able to provide updated and accurate information. This supports the leadership of the institution in making decisions and determining policies on gender. The results of the study have been functionally tested and validated by expert.
\end{abstract}

Keywords: gender equality; gender mainstreaming strategy; agile; DSDM; PUG Renstra

\section{Pendahuluan}

Isu gender selalu diperdebatkan oleh masyarakat, baik di dunia kerja dan pendidikan. Berbagai faktor yang saling terkait yang menyebabkan timbulnya isu Kesetaraan dan Ketidakadilan Gender (KKG).

\footnotetext{
${ }^{*}$ Penulis Korespondensi.

E-mail: anggy@pcr.ac.id
}

Politeknik Caltex Riau (PCR) adalah salah satu Politeknik swasta yang berdiri dalam bidang pendidikan. Politeknik Caltex Riau dengan motto Empowers You To Global Competition yang selalu mengedepankan kedisiplinan, ilmu atau kualitas internal sebagai strategi untuk dapat bersaing dengan politeknik lainnya. Salah satu cara untuk mencapai strategi tersebut adalah dengan menjaga agar tidak terjadi kesenjangan gender sehingga meminimalisir isu KKG, membantu mengedepankan 


\section{TEKNIK, 40 (3), 2019, 196}

dan memperkecil gap atau permasalahan di area KKG di Politeknik. Untuk meminimalisir dari isu KKG dapat digunakan dokumen Restra PUG sebagai pedoman dalam pengembangan sistem informasi ini (Politeknik Caltex Riau, 2018)

Renstra PUG merupakan panduan program pengembangan PCR untuk mempromosikan KKG dan memberikan dukungan sepenuhnya pada kegiatan PUG. Rencana strategi ini akan melibatkan pihak-pihak terkait dari internal maupun eksternal PCR. Renstra PUG berfungsi sebagai patokan atau dasar yang dapat menjadi tolak ukur dalam pelaksanaan PUG di PCR. Rencana ini menampilkan sejumlah strategi yang dipilih Politeknik Caltex Riau untuk isu-isu gender yang ada. Strategis tersebut muncul berdasarkan kajian kondisi terkini tentang kesiapan lembaga dalam melaksanakan pengarusutamaan gender. Hasil kajian tersebut menjadi basis data untuk menentukan program dan indikator capaian program.

Program untuk mempromosikan KKG terbentuk dari PMU PEDP RISTEKDIKTI yang membangun sebuah program bernama Polytechnic Education Development Project (PEDP) ke PCR dengan tujuan agar program PUG dijadikan sebuah strategi yang telah dirancang dengan panduan dari Renstra PUG.

Untuk mendukung pelaksanaan PUG di PCR, maka diperlukan sebuah sistem update dan akurat agar dapat membantu pimpinan PCR selaku pengambil keputusan dalam melakukan penentuan kebijakan. Sistem tersebut juga dapat digunakan sebagai tools pemantau bagi pimpinan PCR dalam Renstra PUG PCR pada target 2018 dan 2022, dikarenakan renstra tersebut sudah berjalan, maka dibutuhkan waktu yang singkat untuk pengembangan sistem informasi tersebut.

Dengan kebutuhan pengembangan sistem informasi yang cepat dan akurat, maka diperlukan sebuah metode pengembangan perangkat lunak yang sesuai, seperti Agile Software Development. Terdapat beberapa cara pengembangan yang dapat dilakukan dalam metode Agile, salah satunya adalah model Dynamic System Development Method (DSDM). Karena, model DSDM dalam pembangunan sistem ini cocok untuk membangun sistem informasi monitoring PUG dan sistem informasi memberikan manfaat dalam mendukung jalannya PUG di PCR.

Beberapa penelitian yang terkait dengan penelitian ini adalah kajian yang dilakukan oleh Desmiwati (2016). Hasil penelitian ini menunjukkan bahwa dengan penerapan Quo Vadis PUG untuk kebijakan di sektor Kehutanan ini digunakan untuk mengambil kasus program perhutanan sosial. PUG yang telah diprogramkan oleh perhutanan sosial yang belum memiliki banyak kemajuan dan sangat jauh dari harapan, meskipun telah ada panduan untuk merumuskan evaluasi program tersebut. Tujuan dari penelitian ini yaitu untuk mewujudkan keadilan gender bagi perempuan pada sektor kehutanan melalui kebijakan publik.

Penelitian selanjutnya dilakukan oleh Ilhamsyah dan Rahmayudha (2017), mengenai dashboard untuk monitoring evaluasi mahasiswa di bidang Pendidikan di Jurusan Sistem Informasi Universitas Tanjungpura (UNTAN) sebagai sarana untuk mengukur kualitas mahasiswa serta mengambil keputusan dalam menentukan strategi dalam pembinaan mahasiswa dilingkungan Jurusan Sistem Informasi UNTAN.

Penelitian berikutnya dilakukan oleh Pribadi (2017) yang membangun sebuah aplikasi bagi pengurus olahraga silat seperti pendaftaran secara online untuk kenaikkan tingkat, pengembangan atlit dalam pembinaan dan manajemen latihan beserta pengelolaan kejuaraan. Pada pembangunan sistem ini digunakan metode Agile dan dua model yaitu model RUP dan DSDM yang akan dijadikan satu metode.

Penelitian yang dilakukan oleh Muslim dan Retno (2014) menghasilkan implementasi Cloud Computing di PT. Erudeye Indonesia yang dibuat dengan menggunakan metode pengembangan sistem Agile Development Methods dengan langkah meliputi perencanaan, implementasi, pengujian, dokumentasi, deployment dan pemeliharaan.

Indah dan Firdaus (2016) juga telah merancang sebuah sistem informasi monitoring untuk mahasiswa penerima beasiswa Bidik Misi. Diperlukan pengembangan sistem monitoring dan evaluasi berbasis web yang dapat mengatasi kendala dan kekurangan tersebut agar tugas dan tanggung jawab sebagai pengelola Bidik Misi menjadi lebih optimal. Dengan pengembangan sistem yang menggunakan Agile method dengan model DSDM.

Adapun penelitian yang dilakukan adalah "Rancang Bangun Sistem Informasi Monitoring Menggunakan Metode Agile dengan Dynamic System Development Model Guna Mendukung Gender Mainstreaming Strategy (Studi Kasus: Politeknik Caltex Riau)". Dengan adanya sistem ini diharapkan dapat membantu pimpinan PCR dalam pengambilan keputusan mengenai Isu KKG yang terkait di PCR. Output yang dihasilkan penelitian ini adalah berupa peringatan mengenai ketidakseimbangan.

\section{Metode Penelitian}

Metode yang digunakan dalam penelitian ini adalah Dynamic System Development Model (DSDM). DSDM adalah pendekatan sistematis menangani sebuah proyek secara efektif dan efisien. DSDM memfasilitasi kerangka yang menarik untuk mengembangkan fungsi dengan cara yang lebih baik. Memberikan fungsi secara efisien dan efektif, dan memuaskan kebutuhan nyata dari proyek. 


\section{TEKNIK, 40 (3), 2019, 197}

DSDM merupakan metode yang dipergunakan dalam pembangunan sistem ini. Pengembangan yang secara sistematis dengan 5 tahap seperti Gambar 1 yaitu Feasibility Study, Business Study, Functional Model Iteration, Design and Build, Implementaion Phase. Feasibility Study dan Business Study tahap dimana memikirkan resiko dalam perkembangan sistem dan pertanyaan apa saja diajukan untuk perkembangan pembuatan sistem dalam penggunaan metode DSDM. Setelah melakukan pengindentifikasi pada kebutuhan user, kebutuhan user yang didapatkan sebagai pedoman dalam pembangunan sistem.

Pada tahap Functional Model Iteration telah terjadi tujuh iterasi dalam rancang bangun sistem. Pada tahap ini perancangan yang dilakukan yaitu perancangan prototipe yang membantu untuk menjamin kualitas pengujian agar sesuai DSDM. Total waktu yang didapatkan dalam perkembangan sistem tahap Functional Model Iteration yaitu 54 hari.

Dikarenakan hasil dari tahap Business Study sudah didapatkan yaitu kebutuhan user dan Functional Model Iteration sudah mendapatkan hasil perancangan prototipe, maka langkah selanjutnya yaitu masuk ke tahap Design and Build. Pada tahap ini terjadi pengimplementasi sistem kedalam bentuk program. Terdapat beberapa penyesuaian dari sisi warna grafik dan tambahan fitur pada tampilan Tabel.

Setelah terbentuknya sebuah sistem, maka tahap terakhir Implementation Phase yaitu dengan melakukan pemeriksaan kebenaran sistem yang dirancang dalam pengujian. Pengujian dilakukan dengan dua metode yaitu pengujian fungsional dan pengujian validasi ahli. Pengujian fungsional dilakukan untuk mengecek apakah sistem sudah berjalan dengan baik. Sedangkan pengujian validasi ahli dilakukan langsung dengan pakar gender dengan menggunakan metode Agile dengan model DSDM.

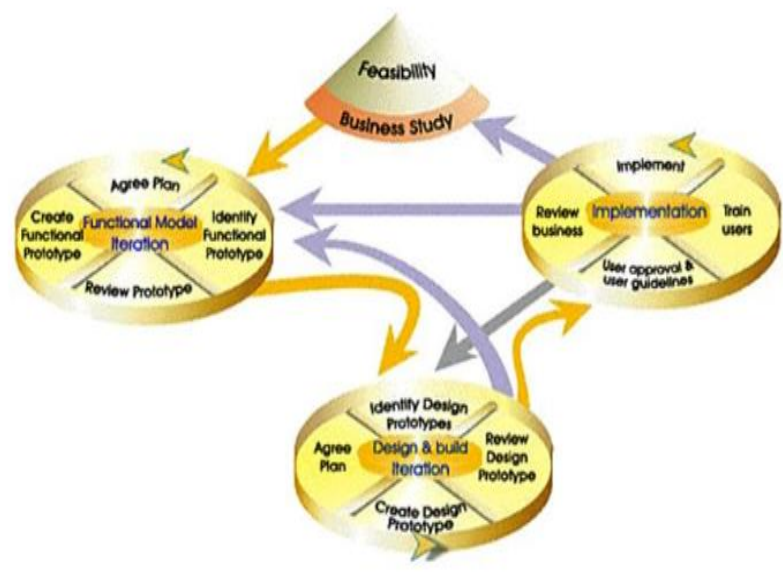

Gambar 1. Siklus DSDM

doi: 10.14710/teknik.v40n3.25704

\section{Hasil dan Pembahasan \\ 3.1 Hasil Pengembangan}

Feasibility study merupakan fase dimana kelayakan pada sistem dalam penggunaan metode DSDM diperiksa. Beberapa pertanyaan yang telah diajukan pada fase ini dengan perkembangan pembuatan sistem yang menggunakan DSDM apakah cocok atau tidak. Apa resiko yang paling penting dan siapa yang akan terlibat.

Dalam proses pengerjaan sistem, user meminta tambahan field untuk pejabat struktural dengan atribut NIP, nama staf, jabatan, jenis kelamin. Pada tahapan Business Study melakukan pengindentifikasi kebutuhan user yang akan dipenuhi sebagai pedoman dalam pembangunan sistem.

\subsubsection{Functional Model Iteration}

Pada tahap ini dilakukan pembuatan perancangan melalui prototipe untuk mendapatkan hasil pembentukkan sistem secara efektif dan kualitas pengujian sesuai. Diketahui total iterasi yang terjadi ada enam, dengan total pengerjaan waktu selama 54 hari dengan beberapa catatan dalam tiap iterasi. Perancangan prototipe pada tahap ini yaitu: iterasi pertama hingga ketujuh.

Pada iterasi pertama, perancangan ini dibuat sesuai dengan kebutuhan dari user. Terdapat tampilan beranda, tentang, tampilan yang mewakili tampilan lainnya dan begitu juga tampilan mahasiswa. Pada iterasi pertama ini, user menerima rancangan prototipe yang dirancang developer. Waktu pengerjaan untuk mendapatkan hasil rancangan prototipe ini sebanyak 12 hari.

Pada iterasi kedua, user memberikan tambahan yaitu tampilan pejabat structural dan dengan 2 hari developer melihatkan hasil dari rancangan untuk tampilan pejabat struktural dan user menyetujui tampilan yang dirancang sesuai.

Pada iterasi ketiga, terdapat tambahan tampilan yaitu tampilan pada mahasiswa perangkatan dan per Program Studi (prodi) diberi tambahan sub menu agar menampilkan detail data. Dengan pengerjaan selama 6 hari dan developer melihatkan perubahan tampilan kepada user. User menolak untuk tampilan mahasiswa per prodi dikarenakan user menginginkan perubahan pada tampilan utama untuk mahasiswa per prodi yaitu tiap prodinya ditampilkan dengan grafik pie dan menampilkan rasio pada masing-masing prodi. Untuk tampilan mahasiswa perangkatan user menerima perancangan tampilan tersebut.

Pada iterasi keempat, setelah melakukan perubahan pada tampilan mahasiswa per prodi dengan waktu 17 hari user menyetujui tampilan yang dirancang oleh user. Pada iterasi keempat user dan developer melakukan pertemuan sebanyak dua kali agar mendapatkan hasil tampilan yang maksimal dan sesuai. 


\section{TEKNIK, 40 (3), 2019, 198}

Pada iterasi kelima dengan waktu tujuh hari developer merancang tampilan yang diinginkan oleh user dan user menyetujui tampilan yang dirancang oleh developer.

Pada iterasi keenam, dengan waktu tiga hari developer melakukan perubahan terhadap tampilan beranda dikarenakan menurut user untuk gambar dianggap mengganggu dan tidak memberikan pengetahuan mengenai rentang rasio yang dibandingkan.

Pada iterasi ketujuh, dengan waktu tujuh hari developer melakukan perubahan terhadap tampilan beranda dikarenakan menurut user pada tampilan grafik pie lebih cocok disandingkan dengan rasio dan data dosen per prodi lebih didetailkan.

\subsubsection{Design and Build}

Design and build merancang sistem sesuai dengan kebutuhan fungsional dan non fungsional. Kebutuhan tersebut sebelumnya telah disepakati oleh user pada tahap Business Study. Setelah kebutuhan selesai maka selanjutnya melakukan perancangan sistem sesuai dengan perancangan yang telah dibuat pada tahap Functional Model Iteration.

\subsubsection{Halaman Beranda}

Gambar 2 dan 3 merupakan halaman beranda. Pada halaman beranda menampilkan grafik mahasiswa keseluruhan dan grafik staf keseluruhan beserta peringatan dalam bentuk warna di rasio Mahasiswa dan rasio staf. Grafik mahasiswa keseluruhan dan grafik staf keseluruhan berfungsi untuk menampilan semua data grafik dari awal tahun proses belajar mengajar di Politeknik Caltex Riau hingga sekarang. Data menunjukkan perbandingan staf terutama mahasiswa apakah terdapat peningkatan atau sebaliknya. Ini memungkinkan pimpinan PCR untuk bisa mendapatkan informasi dan mengambil sebuah keputusan. Pada halaman beranda ini data Mahasiswa dan staf ditampilkan per tahunnya dan datanya realtime. Jika ada penambahan data, secara tidak langsung di sistem datanya akan bertambah secara otomatis. Dapat di lihat pada tahun 2016 terdapat Mahasiswa berjenis kelamin dengan jumlah 198 laki-laki dan 133 perempuan. Pada tahun 2016 staf terdapat 14 laki-laki dan 10 perempuan. Grafik bisa diunduh dalam bentuk gambar sehingga mempermudah pengguna dalam mengelola data.

Gambar 2 dan 3 menunjukkan rasio mahasiswa keseluruhan dan staf keseluruhan. Rasio tersebut didapat dari perbandingan antara laki-laki dengan perempuan. Kolom rasio akan berubah warna dengan perhitungan yang telah ditentukan. Jika kondisi PUG aman maka akan memunculkan warna hijau. Jika kondisi PUG perlu perhatian maka akan memunculkan warna kuning. Jika kondisi PUG perhatian khusus maka akan muncul warna merah. Gambar 4 menunjukkan informasi mengenai berapa rentang rasio yang telah ditetapkan.

\subsubsection{Halaman Statistik}

Halaman statistik menampilkan data mahasiswa dan kepegawaian yang aktif. Data statistik staf ditampilkan dalam bentuk grafik berikut peringatan dalam bentuk warna pada bagian rasio dan tabel. Pada rasio statistik staf terdapat angka rasio dan peringatan dalam bentuk warna di rasio. Grafik statistik yang bisa dimunculkan meliputi data: (1) staf keseluruhan (Gambar 5); (2) dosen per prodi (Gambar 6); (3) Staf Asistant Infrastructure Laboratorium (AIL) (Gambar 7); (4) staf per bagian (Gambar 8); (5) staf kepanitiaan (Gambar 9); dan (6) staf pejabat struktural (Gambar 10).

Gambar 5 memperlihatkan grafik staf keseluruhan. Data tahun yang difilter per jenis kelamin dan total tiap jenis kelamin. Selain itu pengguna juga bisa melakukan pencarian data staf berdasarkan data tahun atau nip atau nama staf atau jenis kelamin. Sedangkan Gambar 6 memperlihatkan grafik dosen per prodi, terdapat data prodi yang difilter per jenis kelamin dan total tiap jenis kelamin. Pada tabel menampilkan data prodi, nama dosen dan jenis kelamin. Jika diklik grafik batang pada halaman utama seperti di Gambar 7, maka akan muncul grafik pie detail setiap prodi. Selain itu pengguna juga bisa melakukan pencarian data staf berdasarkan data prodi atau nama dosen atau jenis kelamin.

Pada Gambar 8 di grafik staf AIL terdapat data total tiap jenis kelamin. Pada tabel staf AIL menampilkan data laboran, nama AIL dan jenis kelamin. Pada gambar 9 di grafik staf per bagian terdapat data per bagian yang difilter per jenis kelamin dan total tiap jenis kelamin. Pada tabel menampilkan data bagian, nama staf dan jenis kelamin. Pada gambar 10 di grafik staf kepanitiaan terdapat data nama kegiatan panitia yang difilter per jenis kelamin dan total tiap jenis kelamin. Pada tabel menampilkan data nip, nama staf, nama kepanitiaan dan jenis kelamin. Pada gambar 11 di grafik staf pejabat struktural terdapat data total tiap jenis kelamin. Pada tabel staf pejabat struktural menampilkan data nip, nama staf, jabatan dan jenis kelamin.

Dashboard juga menunjukkan data terkait mahasiswa, berupa: (1) mahasiswa per angkatan (Gambar 11); dan (2) mahasiswa per prodi (Gambar 13). Gambar 12 menunjukkan grafik mahasiswa per angkatan berikut peringatan dalam bentuk warna di data rasio dan tabel. Gambar 13 menunjukkan grafik di halaman utama, dimana terdapat data mahasiswa tiap angkatan yang difilter berdasarkan jenis kelamin dan total tiap jenis kelamin. Tabel mahasiswa per angkatan menampilkan data angkatan, nama mahasiswa, NIM dan jenis kelamin.

Gambar 14 menunjukkan grafik mahasiswa per prodi, peringatan dalam bentuk warna di rasio dan tabel. Pada grafik di halaman ini terdapat jumlah tiap jenis kelamin. Jika pengguna mengarahkan kursornya ke tabel 
TEKNIK, 40 (3), 2019, 199

tersebut bisa mendapatkan informasi berupa berapa jumlah jenis kelamin yang dipilih.

Dan jika pengguna mengklik grafik tersebut akan muncul tabel seperti gambar 15 Pada tabel Mahasiswa per angkatan menampilkan data angkatan, nama Mahasiswa, NIM dan jenis kelamin. Pada rasio statistik staf terdapat angka rasio dan peringatan dalam bentuk warna di rasio. Pada halaman bawahnya terdapat tabel dengan menampilkan data nama prodi, angkatan, nama mahasiswa, NIM dan jenis kelamin. Selain itu pengguna juga bisa melakukan pencarian data staf berdasarkan data data nama prodi atau angkatan atau nama mahasiswa atau NIM atau jenis kelamin.

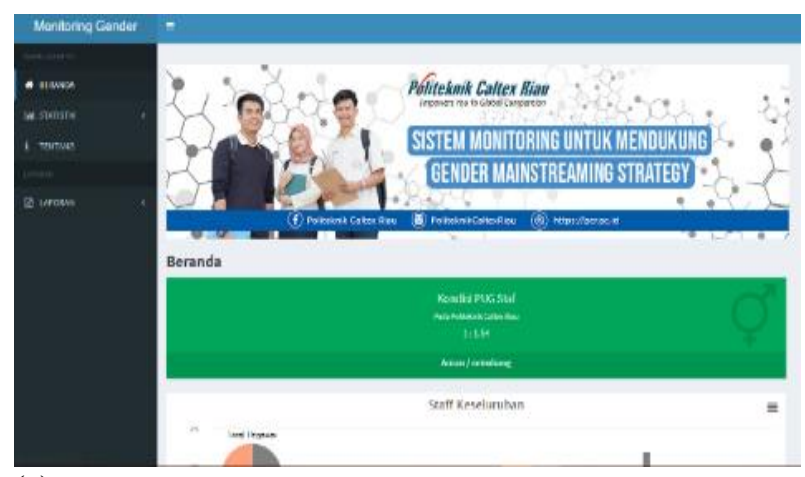

(a)

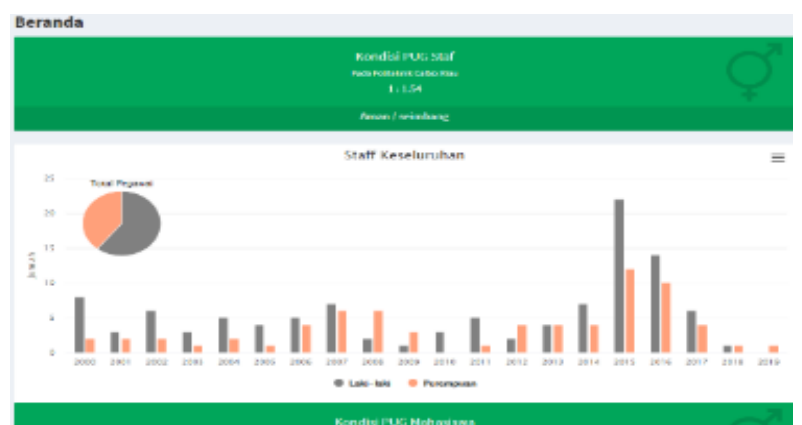

(b)

Gambar 2 (a) Halaman beranda grafik staf (b) Halaman grafik staf

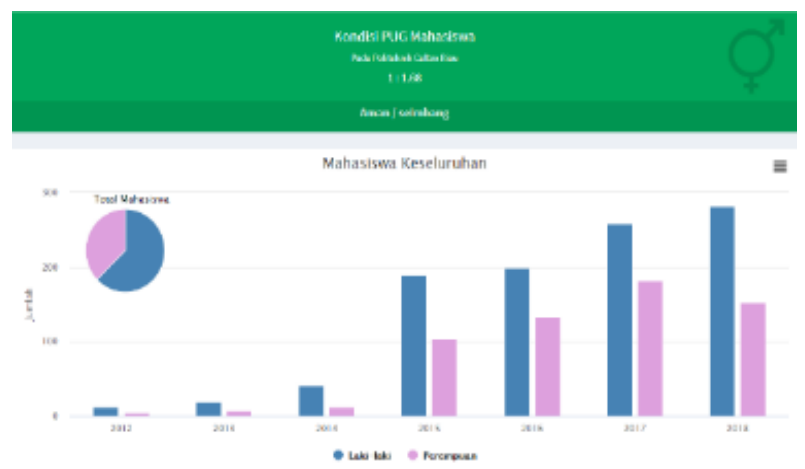

Gambar 3. Halaman beranda grafik mahasiswa

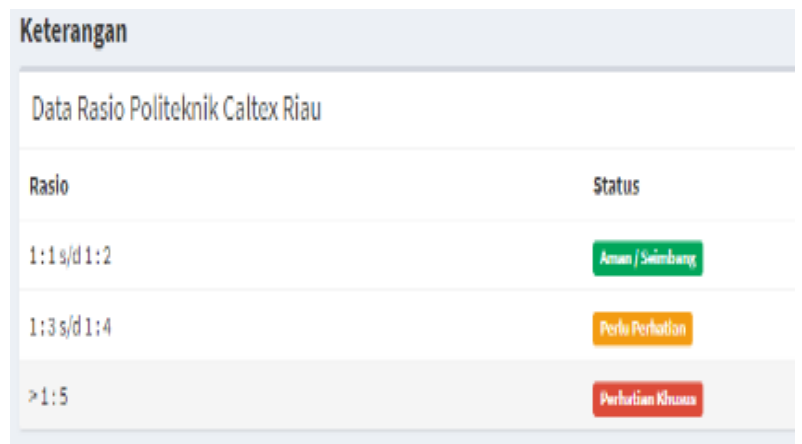

Gambar 4. Halaman beranda keterangan rasio

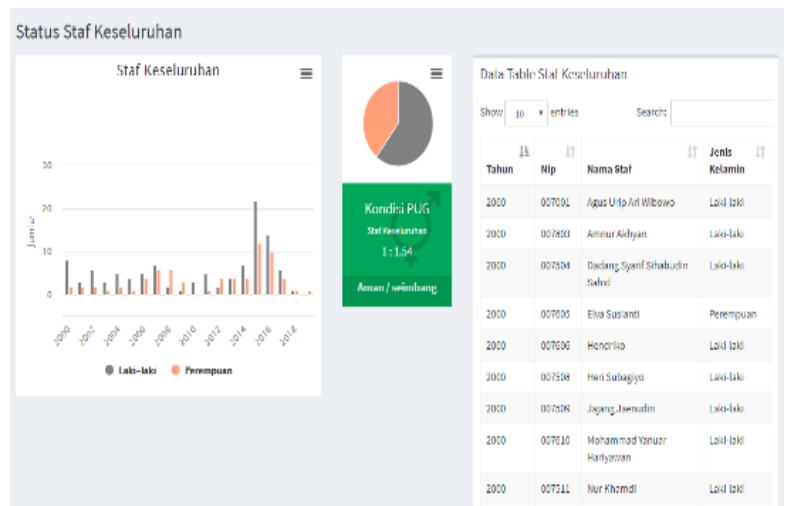

Gambar 5. Halaman staf keseluruhan

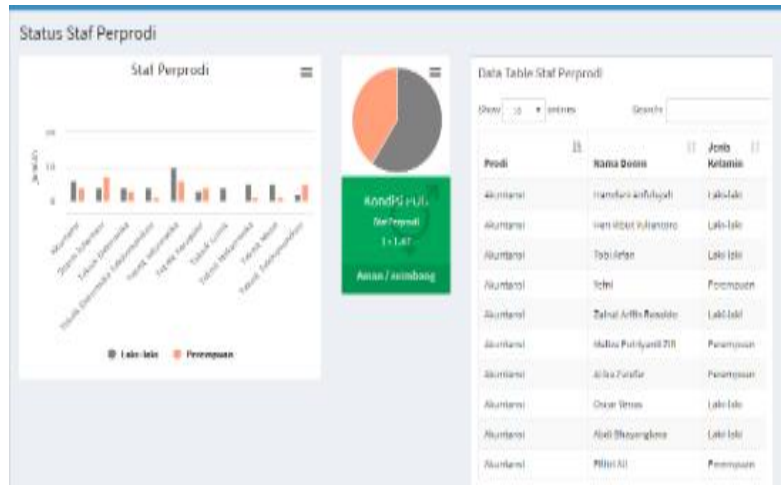

Gambar 6. Halaman dosen per prodi

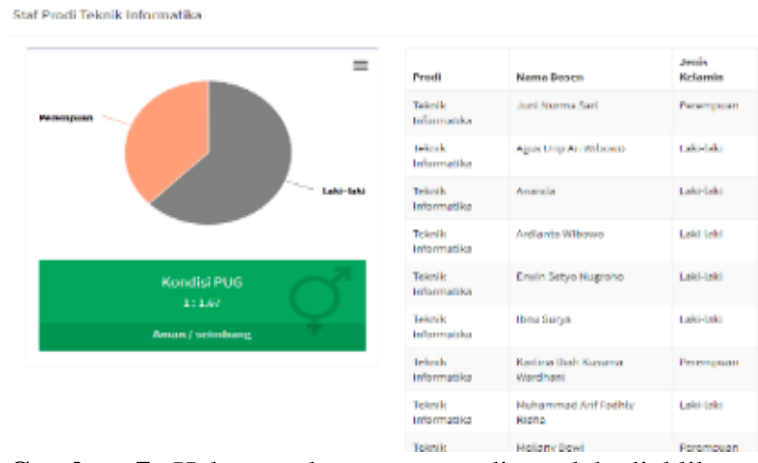

Gambar 7. Halaman dosen per prodi setelah di klik grafik batang 
TEKNIK, 40 (3), 2019, 200

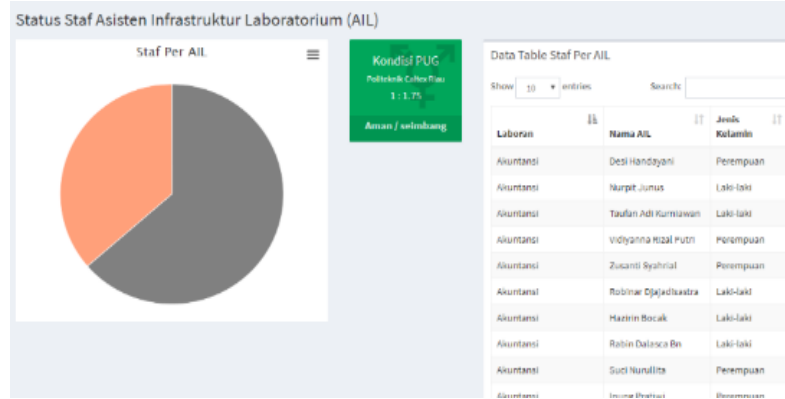

Gambar 8. Halaman staf AIL

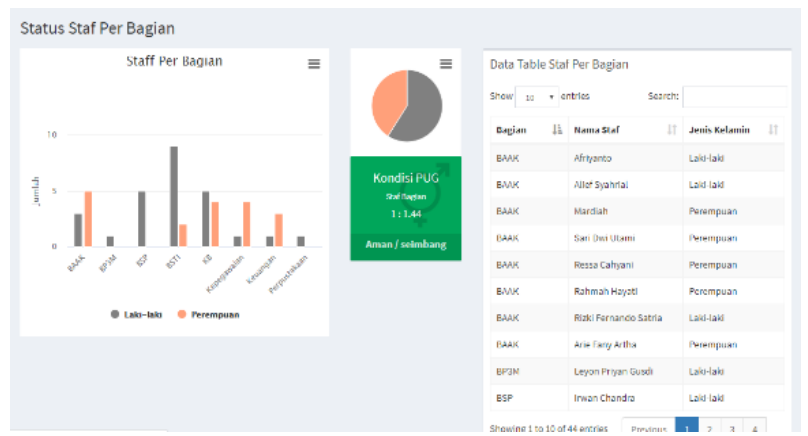

Gambar 9. Halaman staf per bagian

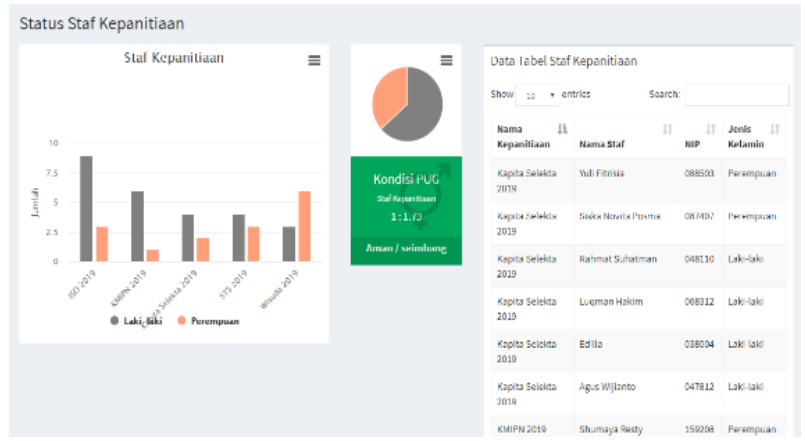

Gambar 10. Halaman staf kepanitian

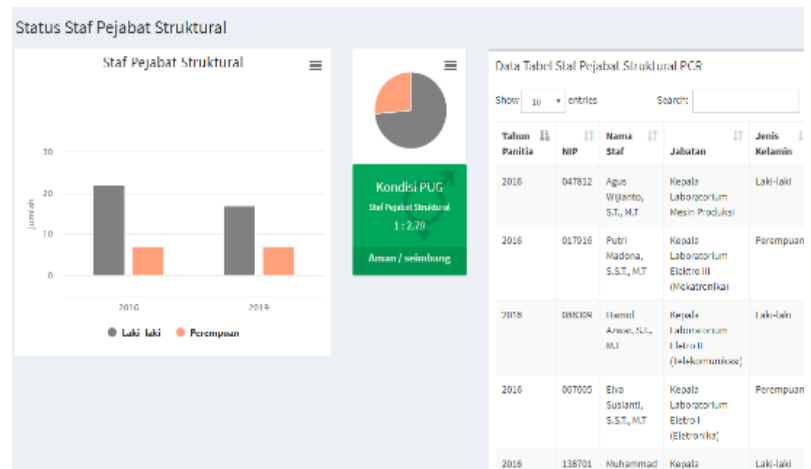

Gambar 11. Halaman staf pejabat struktural

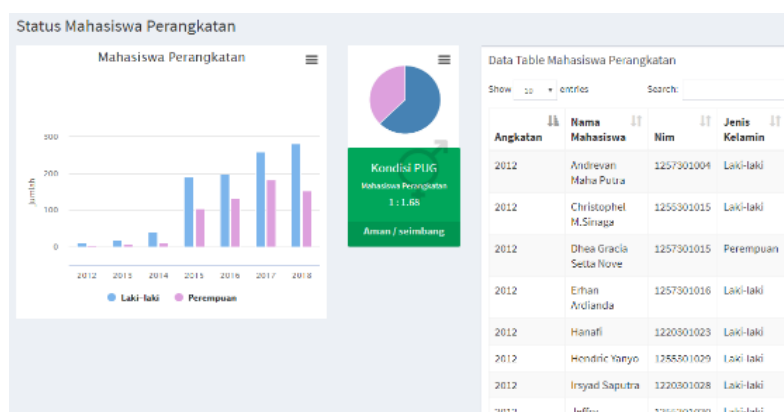

Gambar 12. Halaman mahasiswa per angkatan

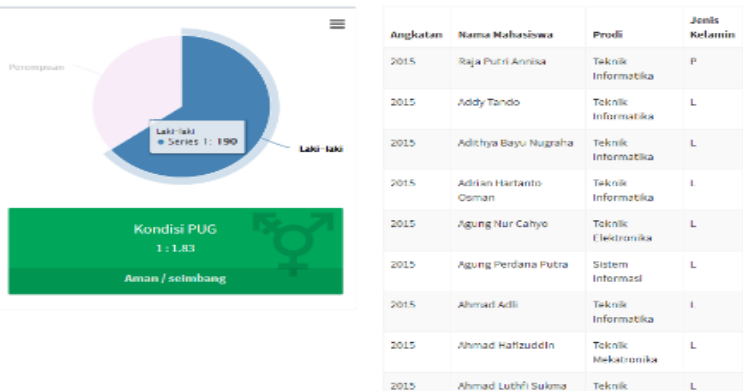

Gambar 13. Halaman modal mahasiswa per angkatan

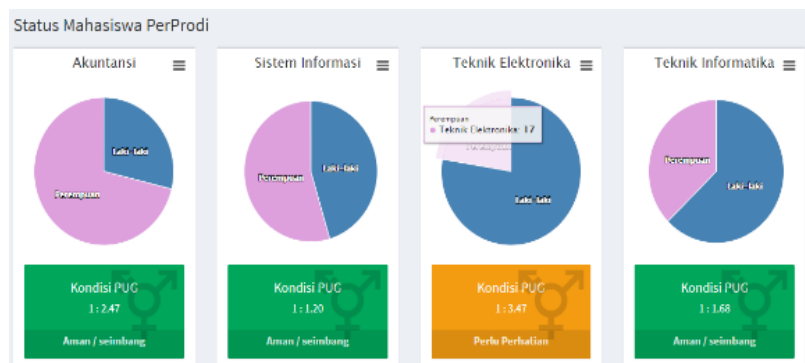

Gambar 14. Halaman mahasiswa per prodi

Prodi Akuntansi

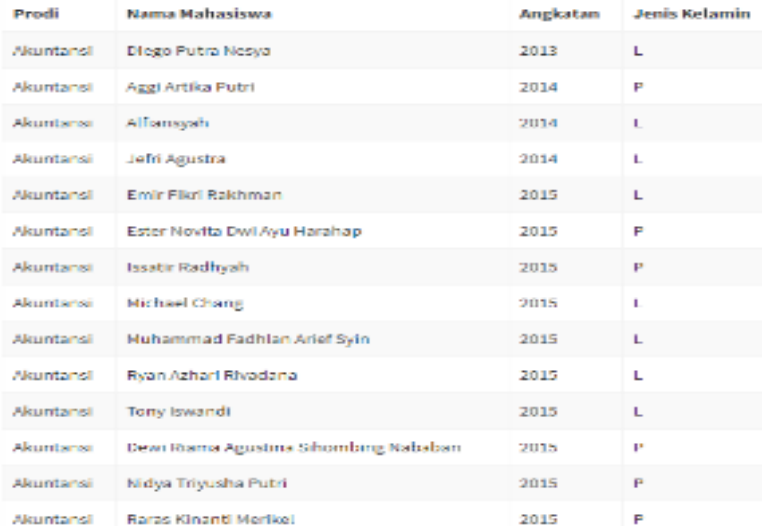

Gambar 15. Halaman modal mahasiswa per prodi 


\section{TEKNIK, 40 (3), 2019, 201}

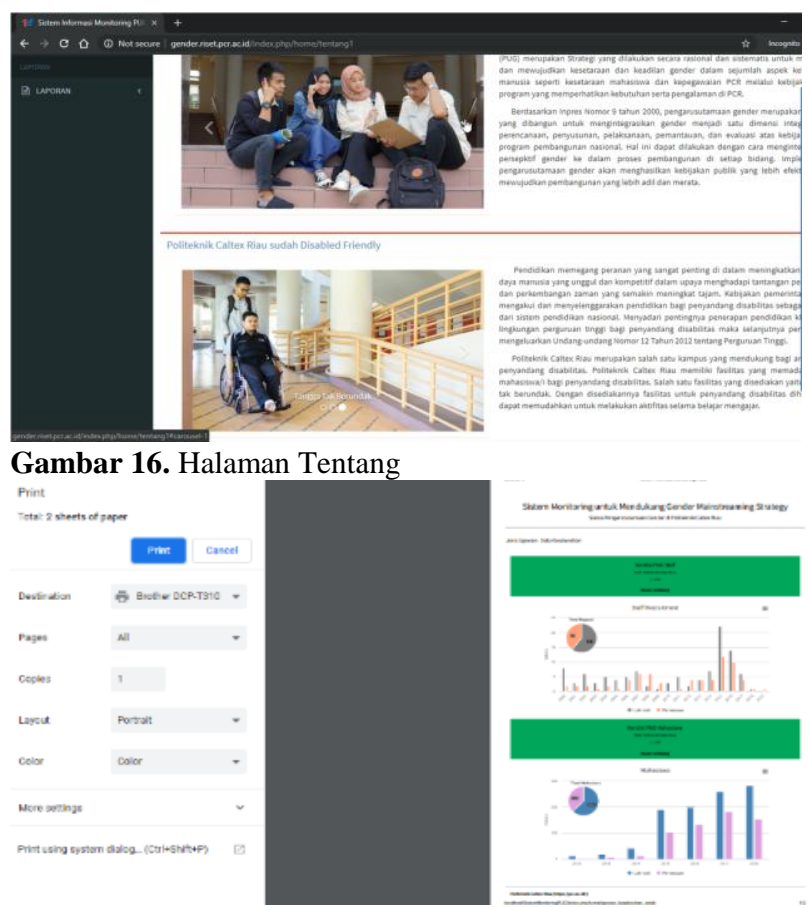

Gambar 17. Halaman Cetak Laporan Keseluruhan
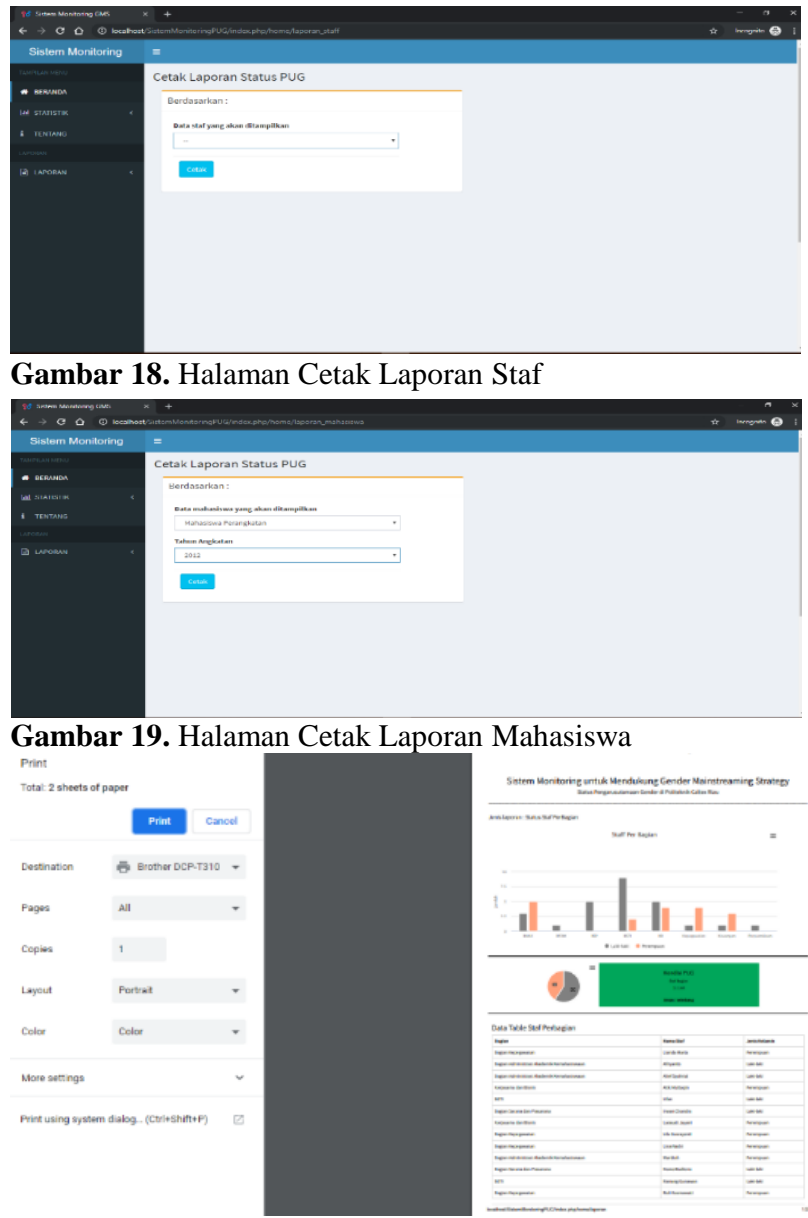

Gambar 20. Contoh Hasil Laporan yang akan di Cetak

\subsubsection{Tentang}

Pada gambar 16 di halaman tentang terdapat penjelasan mengenai apa itu Gender Mainstreaming Strategy dan terdapat penjelasan bahwa PCR sudah Disable Friendly untuk mahasiswa yang disabilitas. PCR memiliki fasilitas yang memadai untuk mahasiswa yang memliki keterbatasan dan membuat mahasiswa merasa nyaman dan tidak merasa kesulitas dalam melakukan kegiatan selama di PCR.

\subsubsection{Laporan}

Laporan yang dihasilkan berupa (1) laporan keseluruhan (Gambar 17); laporan staf (Gambar 18); dan (3) laporan mahasiswa (Gambar 19). Jika kita klik "cetak" dihalaman cetak laporan maka akan menampilkan halaman untuk mencetak halaman mahasiswa/staff (Gambar 20).

\subsubsection{Implementation Phase}

Setelah tampilan beserta fungsional nya bekerja dengan baik dan sesuai, maka sistem akan lanjut ke tahap selanjutnya dengan memeriksa kebenaran sistem yang dirancang. Implementation Phase melakukan pengujian terhadap sistem. Pengujian yang dilakukan ada 2 metode yaitu pengujian fungsional dan pengujian validasi ahli. Pengujian terhadap sistem dengan mengimplementasi sistem ke reviewer menunjukkan apakah sistem sudah sesuai dengan kebutuhan user atau belum. Jika seluruh reviewer sudah menyetujui dengan sistem maka sistem sudah layak digunakan.

\subsection{Analisis Pengujian}

Pengujian dilakukan dengan 2 metode yaitu Pengujian Fungsional dan Validasi Ahli. Pengujian ini dilakukan dengan tujuan agar sistem yang rancang sesuai dengan kebutuhan user dan sistem bermanfaat dan layak digunakan oleh user. Pengujian fungsional ini diperiksa oleh user dengan memeriksa apakah sistem sudah sesuai dengan poin-poin yang dicapai. Pengujian selanjutnya yaitu melakukan pengujian validasi ahli. Pengujian validasi ahli dilakukan oleh pakar Gender. Pada pengujian ini diperiksa apakah sistem sudah sesuai dengan kebutuhan user dan prototipe. Terdapat 7 pakar yang memeriksa sistem pada pengujian validasi ahli. Pengujian ini dilakukan menggunakan metode agile dengan model DSDM. Pengujian validasi ahli ini dilakukan selama 7 hari. Hasil yang didapatkan setelah melakukan pengujian validasi yaitu semua pakar menyatakan bahwa sistem bermanfaat dan sudah layak untuk digunakan di Politeknik Caltex Riau.

Berdasarkan dari hasil pengujian yang dilakukan dengan fitur-fitur pada perancangan terstruktur. Maka sistem telah memenuhi kebutuhan pengguna dengan kesimpulan: (1) sistem bisa menampilkan tampilan beranda; (2) memberikan informasi terpisah staf dan 


\section{TEKNIK, 40 (3), 2019, 202}

mahasiswa; (3) menampilkan informasi bentuk grafik, persentase, tabel; (4) menampilkan informasi rasio jenis kelamin staf berdasarkan keseluruhan, program studi, kepanitiaan, bagian, AIL dan pejabat struktural; (5) menampilkan informasi rasio jenis kelamin mahasiswa berdasarkan tahun dan program studi; (6) menampilkan kegiatan PCR secara terpisah. Dari kesimpulan tersebut maka pengujian setiap butir uji telah diterima oleh user. Sistem sudah dikonfirmasi dengan ahli gender bahwa sistem sudah dapat digunakan. Dengan demikian semua fitur pada sistem telah diimplementasikan dengan baik sehingga dapat membantu dan memudahkan pengguna dalam pengambilan keputusan.

\section{Kesimpulan}

Rancang bangun sistem informasi monitoring menggunakan metode Agile dengan model DSDM telah selesai dilaksanakan. Sistem informasi ini berguna untuk Gender Mainstreaming Strategy pada Politeknik Caltex Riau. Sistem informasi yang dibangun mampu menampilkan informasi yang update dan akurat sehingga mendukung pimpinan institusi dalam pengambilan keputusan dan penentuan kebijakan terhadap gender. Hasil penelitian telah diuji secara fungsional dan divalidasi oleh expert.

\section{Ucapan Terima Kasih}

Terima kasih kepada Politeknik Caltex Riau yang telah mendukung penelitian ini.

\section{Daftar Pustaka}

Desmiwati. (2016). Quo Vadis Pengarusutamaan Gender (PUG) Dalam Kebijakan Publik Di Sekotr Kehutanan. Jurnal Penelitian Ekosistem Dipterokarpa, 2(2).

Ilhamsyah, Rahmayudha, S. (2019). Perancangan Model Dashboard Untuk Monitoring Evaluasi Mahasiswa. Jurnal Informatika:Jurnal Pengembangan IT (JPIT), 1(2).

Indah, D. R., Firdaus, M. A. (2016). Pengembangan Perangkat Lunak Sistem Informasi Monitoring Mahasiswa Bidikmisi Berbasis Web Menggunakan Pendekatan DSDM. Jurnal Informatika, 2(16).

Muslim, M. A., Retno, N. A. (2014). Implementasi Cloud Computing Menggunakan Metode Pengembangan Sistem Agile. Scientific Journal of Informatics, 1(1).

Pribadi, R. M. (2017). Integrasi RUP dan DSDM untuk Rancang Bangun Sistem Infromasi yang Komprehensif. Jurnal SISFOKOM, 01(06).

Politeknik Caltex Riau. Selamat Datang di Kampus Politeknik Caltex Riau. Diakses dari https://pcr.ac.id/, tanggal 25 Juni 2018.

Politeknik Caltex Riau. (2018). Daftar Rencana Strategis Pengarusutamaan Gender Politeknik Caltex Riau (Renstra PUG PCR). Politeknik Caltex Riau.Riau. 